\title{
THE LEGAL FRAMEWORK FOR SPORTS DEVELOPMENT AND THE ENVIRONMENTAL PROTECTION
}

\section{PRAWNE RAMY ROZWOJU SPORTU A OCHRONA ŚRODOWISKA NATURALNEGO}

\begin{abstract}
Sport is an important element of public health, politics and business. The popularity of active sporting is increasing part of society. However, the passive participation in sports events is important too. On the need for active and passive sports is necessary to build sports infrastructure. The dynamic growth of the sports sector makes people to ask the question about its impact on the natural environment. There is actually no major research on this subject and the proof of it can be found in the fact that there are residual and insufficient legal regulations on this matter. Hence, the research hypothesis is that the sport is not a sector indifferent to the environment, and may even pose a rather serious threat. The aim of the research is to analyze the law and EU documents as well as Polish regulations in terms of searching for solutions that protect the natural environment against excessive interference of sport in the environment. The final conclusions indicate on the need to revise the EU and Polish legal system regarding sports sector, to increase the sensitivity on the protection of environment.
\end{abstract}

\section{STRESZCZENIE}

Sport jest istotnym elementem zdrowia publicznego, polityki i biznesu. Czynne uprawianie sportu podejmuje coraz większa część społeczeństwa. Nie mniej ważne jest bierne uczestniczenie $\mathrm{w}$ wydarzeniach sportowych. Na potrzeby czynnego i biernego uprawiania sportu konieczne jest budowanie infrastruktury sportowej. Dynamiczny wzrost sektora sportowego rodzi konieczność postawienia sobie pytania o jego wpływ na środowisko naturalne. Na ten temat właściwie nie prowadzi się 
większych badań, dowodem czego są szczątkowe i niewystarczające regulacje prawne. Stąd hipotezą badawczą pracy jest twierdzenie, że sport nie jest sektorem obojętnym dla środowiska, a może nawet stanowić dla niego dość duże zagrożenie. Celem badań jest analiza przepisów prawa i dokumentów unijnych oraz polskich pod kątem rozwiązań chroniących środowisko naturalne przed nadmierną ingerencją sportu w środowisko. Wnioski końcowe wskazują na potrzebę rewizji unijnego i polskiego systemu prawa dotyczącego sektora sportowego, w celu zwiększenia wrażliwości na ochronę środowiska.

KEYWORDS: environmental protection, the impact of sport on the environment, European law, environmental law, sports facilities, playing sports

SŁOWA KLUCZOWE: ochrona środowiska, oddzialywanie sportu na środowisko, prawo europejskie, prawo ochrony środowiska, obiekty sportowe, uprawianie sportu

\section{WPROWADZENIE}

Sport, jego uprawianie i organizacja, najczęściej jest postrzegany jako instrument troski o zdrowie czy też jako jeden ze sposobów dostarczenia masowej rozrywki. Stąd też ustawodawca w przepisie art. 2 ust. 1 ustawy z dnia 25 czerwca 2010 r. o sporcie (t.j. Dz.U. z 2018 r. poz. 1263) twierdzi, że „sportem są wszelkie formy aktywności fizycznej, które przez uczestnictwo doraźne lub zorganizowane wpływają na wypracowanie lub poprawienie kondycji fizycznej i psychicznej, rozwój stosunków społecznych lub osiągnięcie wyników sportowych na wszelkich poziomach".

Sport jest wiązany z prawem człowieka do odpoczynku, który ma swoje korzenie w biblijnym nakazie odpoczynku po całotygodniowej pracy zapisanym w Księdze Rodzaju 2.3 (Pater, 2012, s. 213; Krajewski, 2017, s. 203 i nast.). Obecnie prawo człowieka do odpoczynku, również poprzez uprawianie i organizowanie sportu, wyprowadzane jest $\mathrm{z}$ postanowień normatywnych zawartych w konwencjach i deklaracjach międzynarodowych dotyczących praw człowieka. Takie postanowienia znajdują się m.in. w przepisie art. 24 Powszechnej Deklaracji Praw Człowieka oraz w przepisie art. 31 ust. 2 Karty Praw Podstawowych Unii Europejskiej. Co ciekawe, o prawie do odpoczynku czy urlopu nie wspomina się w Europejskiej Konwencji Praw Człowieka z 1950 r. 
Sport jest zjawiskiem dość starym. Różne jego formy występowały m.in. w antycznej Grecji i antycznym Rzymie. Czynne uprawianie sportu w starożytnej Grecji było dość rozpowszechnione; organizowane były tam pierwsze olimpiady, czyli zawody m.in. w takich dyscyplinach, jak: skok w dal, rzut dyskiem oraz oszczepem. Sport głównie uprawiali młodzi chłopcy, a więc nie było to zjawisko powszechne (Słapek, 2010, s. 13-40; Winniczuk, 1983, s. 559-560). Co ciekawe, Rzymianie raczej czynnie sportu nie uprawiali, lubili natomiast obserwować takie zawody, w tym walki gladiatorskie.

Dość odmiennie kształtuje się współczesna wizja sportu, w której coraz większa część społeczeństwa uprawia czynnie aktywność fizyczną. Według raportu Ministerstwa Sportu z 2017 r. 39\% Polaków jest aktywnych sportowo, zaś 41\% gospodarstw domowych wydaje na sport przeciętnie 1017 zł na rok. Wydatki publiczne na kulturę fizyczną wynoszą 4,6 mld zł, w większości jednak środki te pochodzą z budżetów samorządowych. Pozytywną konsekwencją tego zjawiska jest zmniejszenie się liczby zgonów i zawałów oraz zmniejszenie się poziomu absencji w pracy. Najbardziej popularne współczesne typy sportu to: gra w piłkę nożną, piłkę ręczną, tenis ziemny, lekkoatletyka, pływanie i jazda rowerem (Ministerstwo Sportu i Turystyki, 2016). Powyższe dane dotyczące Polski nie odbiegają od średnich danych europejskich.

Według badań specjalnych zleconych przez Eurobarometr w 2009 r. 40\% obywateli Unii Europejskiej twierdziło, że uprawia czynnie sport. Najrzadziej aktywność fizyczną wykazują obywatele Bułgarii (82\%) i Grecji (79\%). Należy też stwierdzić, że analogicznie do danych dotyczących Polski, podobne rodzaje sportu uprawiane są przez obywateli innych państw unijnych (badanie specjalne Eurobarometru, 2009).

Na potrzeby czynnego uprawiania sportu i biernego uczestnictwa w zawodach sportowych konieczne jest zbudowanie odpowiedniej infrastruktury sportowej. Niezależnie od formy uprawiania sportu - jest to widowisko i to od najdawniejszych czasów. Ludzie nie tyle chcą sami uprawiać jakąś dyscyplinę, raczej preferują uczestniczyć w zmaganiach sportowych.

Powracając do antycznego Rzymu, a nawet i antycznej Grecji, dla potrzeb zaspokojenia potrzeb społecznych polegających na oglądaniu rywalizacji sportowej czy walk sportowych i nie tylko - budowane były wielkie amfiteatry. Współcześnie najbardziej znanym amfiteatrem jest rzymskie 
Koloseum. Ale w wielu miastach włoskich, m.in. w Lecce, mieście położonym na południu Włoch, zachowały się nawet dwa amfiteatry, wcześniejszy grecki i późniejszy rzymski. Jak wielkie były to obiekty, wystarczy wspomnieć, że Circus Maximus, największy w dziejach ludzkości stadion-hipodrom, mógł pomieścić ok. 250 tys. widzów (Dupont, 2011, s. 221; Ciechanowicz, 1989, s. 64 i nast.). Do dzisiaj nie udało się zbudować większego stadionu. Obecnie największym tego typu obiektem jest stadion w Bristolu (Stany Zjednoczone), który mieści ok. 153 tys. widzów.

Motywem budowy amfiteatrów była potrzeba dostarczenia przez władzę publiczną i bogatszych obywateli rozrywki dla uboższych sfer społeczeństwa, zgodnie ze słynną rzymską maksymą: panem et circenses, czyli chleba i igrzysk. Zgoła odmienny jest współczesny motyw wznoszenia obiektów sportowych, a mianowicie ich budowa jest podyktowana potrzebą troski o zdrowie publiczne społeczeństwa, ale też i względami biznesowymi. Z rzadka zaś przebija motyw polityczny, jak na przykład budowa przez Rosję obiektów sportowych w Soczi na potrzeby igrzysk zimowych w 2014 r. Władze tego państwa w ten sposób zyskały międzynarodowy aplauz, jednak obiekty te obecnie stoją $\mathrm{w}$ dużej mierze niewykorzystywane i popadają w ruinę. Władze Rosji na ten cel wydatkowały niebagatelną sumę ok. 50 mld dolarów. W ruinę popadło wiele innych obiektów sportowych budowanych niekoniecznie w sposób uzasadniony, bez wizji ich przyszłego wykorzystania. Przykładem są obiekty pozostałe po olimpiadzie zimowej w Sarajewie (1984) oraz po olimpiadzie letniej w Atenach (2004) (Knowiton, 2016).

Działacze sportowi, władze polityczne, ale też i teoretycy zajmujący się wszelką aktywnością sportową dość długo utrzymywali, że sport - podobnie jak turystyka - jest sektorem czystym, a więc niemającym większego wpływu na środowisko naturalne. Współcześnie już tak się nie twierdzi, bowiem prawie każdy sport, może poza szachami, ma wpływ na środowisko naturalne, emitując hałas, produkując odpady, a także dewastując tereny zielone zajmowane pod budowę infrastruktury sportowej (Sitek, 2007, s. 31-33; Štulajer, Štulajter, 2016, s. 381 i nast.).

Nie można zatem utrzymać jako prawdziwą hipotezę badawczą, że sport jest aktywnością obojętną dla środowiska. Sport zorganizowany i uprawiany indywidualnie zawsze może wpływać negatywnie na środowisko naturalne. 
Ma to miejsce w przypadku budowy wielkich obiektów wraz z infrastrukturą towarzyszącą i transportową, jak i infrastrukturą przeznaczoną zasadniczo dla indywidualnego wykorzystywania, jak ścieżki rowerowe oraz trasy narciarskie. Analiza zjawiska oddziaływania sportu na środowisko nie została w sposób należyty opracowana w literaturze polskojęzycznej, ale też i anglojęzycznej.

O możliwej skali oddziaływania sportu na środowisko naturalne świadczy przede wszystkim istniejąca i tworzona infrastruktura. Tylko w $2012 \mathrm{r}$. w Polsce zbudowano 22 tys. hal sportowych i sal gimnastycznych. W Polsce znajduje się ponad 45 tys. boisk sportowych. Do tego należy dodać jeszcze infrastrukturę treningowo-widowiskową, hotelową, drogową i lotniczą (Program Rozwoju Sportu do 2020). Z kolei według inwentaryzacji przeprowadzonej przez Ministerstwo Sportu i Turystyki w 2017 r. wynika, że w 2016 r. w Polsce było 368 obiektów lekkoatletycznych, a dodatkowo było budowanych 117 takich obiektów (Ministerstwo Sportu i Turystyki, 2017). Dane te pokazują skalę istniejącej infrastruktury sportowej i obszar możliwego oddziaływania jej na środowisko naturalne.

\section{WSPÓŁCZESNA KONCEPCJA ROZWOJU SPORTU}

Współczesny rozwój sportu, tak czynne jego uprawianie, jak i bierne uczestnictwo w wydarzeniach sportowych, wymaga ogromnych inwestycji infrastrukturalnych. W wielu krajach, w tym i w Polsce, budowane są nowe obiekty sportowe na skalę masową, m.in. buduje się ścieżki rowerowe, korty tenisowe, baseny i obiekty wielofunkcyjne. W procesie tym biorą udział prywatni przedsiębiorcy, jak i instytucje publiczne, zwłaszcza samorządy. Bardzo rzadko ma zastosowanie partnerstwo publiczno-prywatne przy budowie infrastruktury sportowej (Kłobukowska, 2015, s. 70-78). Niestety, kompleksowe dane o tych obiektach nie są gromadzone nawet w raportach GUS. W 2017 r. GUS wydał raport pt. „Infrastruktura komunalna 2017”, w którym nie znalazła się żadna zagregowana informacja dotycząca budowy infrastruktury sportowej w gminach.

Należy też być świadomym tego, że sama definicja infrastruktury sportowej nie jest w literaturze jednoznaczna. Jednak ze względu na to, że temat ten jest dla tego opracowania dość oboczny, można przyjąć roboczo definicję opisową autorstwa J. Kłobukowskiej. Według niej infrastruktura sportowa 
obejmuje nie tylko obiekty sportowe, ale także powiązane z nimi usługi, takie jak: gastronomia, miejsca zabaw dla dzieci, sklepy z pamiątkami sportowymi, miejsca noclegowe, sale szkoleniowe i konferencyjne, muzea sportu. Same obiekty sportowe mogą jeszcze zostać podzielone na odrębne kategorie obiektów, takie jak: pływalnie, boiska sportowe, hale sportowe czy stadiony (Kłobukowska, 2015, s. 72).

\section{Sport a prawo Unii Europejskiej}

Sektor sportu jest przedmiotem licznych regulacji prawnych, unijnych i krajowych. W prawie, a właściwie w polityce Unii Europejskiej znajdują się dwie księgi dedykowane bezpośrednio lub pośrednio rozwojowi sportu. Pierwsza z nich to Biała Księga na temat sportu [Com(2007)391 final] wydana przez Komisję Europejską 11 lipca 2007 r. W dokumencie tym wskazano na kilka wymiarów sportu. Pierwszym z nich jest jego rola społeczna. Sport przyczynia się do poprawy zdrowia publicznego. Dalej jest wymiar gospodarczy sportu i tutaj KE wskazuje na potrzebę finansowania zwłaszcza zdarzeń sportowych ze środków publicznych. Dla sportu ważny jest też wymiar organizacyjny, polegający na ułatwieniu w przemieszczaniu się uczestnikom imprez sportowych pomiędzy krajami. W końcu, według KE, sport przyczynia się do wzmocnienia dialogu społecznego.

Efektem Białej Księgi było przygotowanie dokumentu roboczego służb Komisji UE, pt. „Unia Europejska a sport. Tło i kontekst” [SEC(2007)935 final, 11.7.2007] oraz komunikatu Komisji pt. „Rozwijanie europejskiego wymiaru sprawiedliwości” [COM(2011) 12 final, 18.1.2011]. Ważnym elementem była też rezolucja Rady Europejskiej w dziedzinie sportu, na podstawie której wdrożony został program rozwoju sportu przewidziany na lata 2014-2017 (Dz.U. UE C 183 14.6.2014). W tych dokumentach nacisk szczególny został położony na potrzebę edukacji prowadzonej w ramach wszelkich aktywności sportowych, która winna mieć na celu kształtowanie u uczestników postaw i zachowań zmierzających m.in. do ochrony środowiska.

Drugim ważnym dokumentem dotyczącym bardziej infrastruktury sportowej jest Zielona Księga bezpieczeństwa usług zakwaterowania turystycznego [COM(2014) 464 final]. Wydanie tego dokumentu powodowane było potrzebą uregulowania pewnych kwestii związanych z zakwaterowaniem ro- 
snącej liczby turystów w Europie. Jak wskazano w tym dokumencie, w latach 2012-2013 Europa przyjęła najwięcej na świecie turystów. Częścią ruchu turystycznego jest turystyka sportowa i w konsekwencji również budowa hoteli oraz innych zespołównoclegowych wokół obiektów sportowych.

\section{Sport a prawo polskie}

Sport jest jednym z ważniejszych obszarów aktywności organów publicznych i społecznych również dla polskiego ustawodawcy. Podstawowe znaczenie ma ustawa z 21 sierpnia 1997 r. o gospodarce nieruchomościami (t.j. Dz.U. z 2018 r. poz. 2204). Na podstawie przepisu art. 6 ust. 6 obiekty sportowe są uznawane za cele publiczne, niezależnie od tego, czy są realizowane ze środków publicznych, prywatnych, czy w ramach partnerstwa publiczno-prywatnego. Jednak w ustawie tej nie ma żadnego odniesienia do powiązania realizacji celów publicznych, w tym obiektów sportowych, z potrzebą ochrony środowiska.

Organizacja życia sportowego oparta jest $\mathrm{z}$ kolei na ustawie $\mathrm{z}$ dnia 25 czerwca 2010 r. o sporcie (t.j. Dz.U. z 2018 r. poz. 1263). Dla szczególnego wydarzenia sportowego, na potrzeby którego wybudowano pięć stadionów wraz z infrastrukturą, sporządzona była specustawa z 7 września 2007 r. o przygotowaniu finałowego turnieju mistrzostw Europy w piłce nożnej (t.j. Dz.U. z 2007 r. poz. 1372) (dalej: ustawa Euro 2012). W tym akcie prawnym dość wyraźnie ustawodawca odniósł się do związku inwestycji strukturalnych i potrzeby ochrony środowiska naturalnego (Golba, 2014). Kolejnym ważnym dokumentem jest Program Rozwoju Sportu do roku 2020 z 6 lipca 2015 r., który obowiązuje do dzisiaj.

\section{Sport a środowisko naturalne}

Z przedstawionych powyżej argumentów wyprowadzonych $\mathrm{z}$ analizy różnych dokumentów, w tym o charakterze normatywnym, wynika, że sport jest niezwykle ważną sferą aktywności społecznej, politycznej i biznesowej, i to zarówno w skali makro, jak i mikro. Pozytywne spostrzeganie sportu, jego promocja i finansowanie ze środków również publicznych są powodowane przede wszystkim względami zdrowia publicznego oraz potrzebą zapewnienia społeczeństwu rozrywki. 
Niemniej jednak dość rzadko w aktach prawnych lub w innych oficjalnych dokumentach jest uwidaczniane oddziaływanie sportu na środowisko naturalne. Już na samym początku można stwierdzić, że wpływ ten może być i bywa negatywny. Sport to przecież budowa licznych obiektów sportowych wraz z całą infrastrukturą towarzyszącą. Jak to zostało już wcześniej napisane, są to obiekty gastronomiczne, handlowe, hotelowe, a także drogi, parkingi bądź lotniska. Sport, zwłaszcza masowy, uprawiany czynnie czy biernie, produkuje znaczną ilość odpadów stałych, ciekłych oraz powoduje emisję hałasu. Przemieszczanie się znacznej liczby uczestników większych wydarzeń sportowych nierzadko prowadzi do dewastacji terenów zielonych.

\section{Unijne zabiegi na rzecz ochrony środowiska w działaniach sportowych}

Negatywne oddziaływanie sportu na środowisko naturalne nie zawsze jest uwzględniane $\mathrm{w}$ dokumentach publicznych czy aktach normatywnych dotyczących rozwoju sportu. Ważnym z tego punktu widzenia dokumentem jest dokument roboczy służb Komisji - „Unia Europejska a sport. Tło i kontekst” - dokument towarzyszący dołączony do Białej Księgi w sprawie sportu [SEC(2007) 935 final 11.7.2007]. W pkt 2.8 dokumentu została przedstawiona kwestia relacji sportu do jego otoczenia, jakim jest środowisko naturalne. Według twórców dokumentu sport może wpływać na naturę, na ilość wytwarzanych odpadów oraz na pogorszenie stanu bioróżnorodności. Stąd Komisja Europejska proponuje pewne działania czy nawet instrumenty, które powinny tym zjawiskom zapobiec.

Proponuje się wprowadzenie tzw. zielonego sportu (greening of sport). W tym celu Komisja Europejska rekomenduje wprowadzenie odpowiedzialnego zarządzania hałasem, wprowadzenie do zamówień publicznych realizowanych w obszarze infrastruktury sportowej dodatkowego kryterium ochrony środowiska, ograniczenie emisji dwutlenku węgla, organizację składowiska odpadów po imprezach sportowych oraz rewitalizację ziemi i wody zanieczyszczonej w efekcie wydarzeń sportowych (przywrócenie do stanu pierwotnego - restitio in integrum). Wdrożenie tych instrumentów pozwoli na budowania odpowiedzialnego zarządzania wydarzeniami sportowymi, które polega na jednoczesnym połączeniu ze sobą kilku czynników, tj. potrzeb społecznych, 
celów politycznych i biznesowych z potrzebami środowiska naturalnego. W tym celu wydarzenia sportowe winny być promowane nie jako przedsięwzięcia komercyjne, ale jako imprezy kulturalne, społeczne i środowiskowe.

Już 19 marca 2001 r. Unia Europejska wprowadziła rozporządzenie 761/2001 Parlamentu Europejskiego i Rady Europejskiej w sprawie dobrowolnego uczestnictwa organizatorów we wspólnotowym ekozarządzaniu i audycie [Regulation (EC) $N^{\circ} 761 / 2001$ of the European Parliament and of the Council of 19 March 2001 allowin gvoluntary participation by organisations in a Community eco-management and auditscheme (EMAS)]. Uczestnicy programu EMAS godzą się na kontrolę ich wewnętrznego prawa pod względem respektowania zasad ochrony środowiska naturalnego, gromadzenia odpowiednich środków finansowych na ochronę środowiska, budowania wiarygodności wobec władz lokalnych.

W konsekwencji rozporządzenia 761/2001 Komisja wydała podręcznik, w którym znalazły się wskazówki, w jaki sposób należy przeprowadzać zamówienia publiczne na budowę m.in. infrastruktury sportowej oraz na organizację imprez sportowych (Buyinggreen). Jest to dokument skierowany głównie do władz lokalnych. Zawiera on pouczenia w zakresie kryteriów, jakimi winny się one kierować przy budowie obiektów sportowych.

Przy rozbudowie infrastruktury sportowej należy również uwzględnić postanowienia dyrektywy 85/337/EWG dotyczącej oceny wpływu inwestycji publicznych i prywatnych na środowisko (Jendrośka, 1997, s. 33 i nast.) łącznie z dyrektywą 97/11/WE zmieniającą dyrektywę 85/337/EWG (Dz.U. U.E. L 73, z 14.03.1997, s. 7-15) oraz dyrektywę 2001/42 PE i RE z 27 czerwca 2001 r. w sprawie oceny wpływu niektórych planów i programów na środowisko (Dz.U. U.E. L 197 z 21.7.2001, s. 30-37). Pierwsza z nich dotyczyła wyłącznie inwestycji, druga zaś jest dopełnieniem pierwszej, bowiem obejmuje również ocenę ewentualnego wpływu na środowisko już samych planów oraz programów na etapie ich przygotowywania. Istotnym elementem obu aktów prawnych są konsultacje społeczne, ale także konsultacje przeprowadzane z innymi organami administracji ochrony środowiska, dostarczenie przez inwestora informacji o oddziaływaniu inwestycji na środowisko, a nawet jeśli to konieczne - prowadzenie konsultacji z władzami krajów ościennych w stosunku do inwestycji. 
Dość ważnym dokumentem unijnym jest wspomniana powyżej Zielona Księga bezpieczeństwa usług zakwaterowania turystycznego. W dokumencie tym kładziony jest nacisk na takie kwestie, jak: bezpieczeństwo zakwaterowania turystycznego, zwiększenie konkurencyjności sektora turystycznego, stabilności europejskiej turystyki. W tym celu planowano ustanowić organy odpowiedzialne za monitorowanie bezpieczeństwa usług, procedur wymiany informacji, współpracy administracji, systematycznego gromadzenia danych. Kwestie ochrony środowiska pozostały właściwie nieporuszone.

\section{Polskie działania na rzecz ochrony środowiska w działaniach sportowych}

Wyraźnych powiązań pomiędzy inwestycjami w infrastrukturę sportową a oddziaływaniem ich na środowisko można się doszukać w ustawie Euro 2012. Powołane wówczas spółki celowe były zobowiązane do przygotowania dokumentacji na temat pozyskania decyzji o ustalenie warunków zabudowy oraz o środowiskowych uwarunkowaniach (art. 13 ust. 2 pkt 1). Ta druga decyzja winna być uzyskana razem z oceną oddziaływania inwestycji na środowisko (art. 23 ust. 2 pkt 5). W końcu decyzja o ustaleniu lokalizacji winna zawierać warunki wynikające z prawnie chronionych potrzeb środowiska.

Ze sprawozdania Ministerstwa Sportu i Turystyki wynika, że Ministerstwo Środowiska w okresie przygotowań do Euro 2012 podejmowało w zakresie ochrony środowiska działania miękkie i twarde. Do tych pierwszych należy zaliczyć edukację potencjalnych kibiców w zakresie proekologicznych zachowań (Szafrańska, Szafrański, 2014, s. 211 i nast.). Działanie to wynikało z faktu promowania Polski jako kraju bogatego w walory naturalne. W zakresie działań twardych podejmowano takie przedsięwzięcia, jak: kontrola postępowań administracyjnych, na podstawie których wydano decyzje o oddziaływaniu na środowisko takich inwestycji, jak: budowa dróg krajowych, rozbudowa lotniska Ławica w Poznaniu czy we Wrocławiu. Pojęto również działania z zakresu usprawnienia zrzutu odpadów płynnych między prawobrzeżną a lewobrzeżną Warszawą (Ministerstwo Sportu i Turystyki, 2011).

Dużo uwagi wpływowi sportu na środowisko naturalne zostało poświęcone w Programie Rozwoju Sportu do Roku 2020; niestety, jest to tylko projekt rządowy, który nie został nigdy formalnie przyjęty. Widnieje na 
stronach Ministerstwa Sportu [file:///Users/Bronek/Downloads/Program_ Rozwoju_Sportu_do_roku_2020_-_wersja_z_dnia_6_lipca_2015.pdf; dostęp: 29.01.2019]. Na stronie 150 dokumentu stwierdzono, że przy okazji realizacji zamierzeń infrastrukturalnych w obszarze obiektów sportowych należy wspierać ze środków publicznych takie inicjatywy, które zmierzają do rewitalizacji terenów zdegradowanych, oraz projekty, które zmierzają do zmniejszenia zanieczyszczenia powietrza i promowania działań służących zmniejszeniu hałasu.

\section{Podsumowanie}

Podstawowym wnioskiem, jaki płynie z powyższego opracowania, jest brak dostatecznej uwagi władz publicznych, ale też i badaczy na negatywny wpływ działań sportowych na środowisko. Kwestie społeczne, biznesowe i polityczne przesłaniają możliwość określenia skali negatywnych skutków sportu w środowisku naturalnym. Wymaganie wyłącznie spełnienia kwestii formalnych, takich jak pozwolenie, jest instrumentem niewystarczajacym.

Przede wszystkim należałoby zacząć gromadzić informacje na temat negatywnych skutków sportu w środowisku. Takie dane powinny być agregowane przez władze samorządowe, państwowe, a w ramach Unii Europejskiej również przez Komisję Europejską.

Uzyskane w ten sposób dane mogą być podstawą do dalszej pracy w obszarze ochrony środowiska. Badania takie winny być prowadzone przez ekologów, biologów, ornitologów i innych specjalistów. Szczególne zadanie czeka jednak prawników, którzy w oparciu o dane naukowe powinni dokonać rewizji prawa unijnego i polskiego, a także prawa innych państw członkowskich pod kątem zwiększenia poziomu ochrony środowiska naturalnego w szeroko rozumianym sektorze sportu. 


\section{Literatura}

Ciechanowicz, J. (1989). Rzym, ludzie i budowle, Warszawa: PIW. ISBN 830601503.

Dupont, F. (2011). La vita quotidiananella Roma repubblicana, Bari: Editori Laterza. ISBN 9788842060369.

Golba, J. (2014). Inwestycje sportowe celu publicznego, Samorząd Terytorialny R.24 nr 6/2014, s. 73-83. ISSN 0867-4973.

Jendrośka, J. (1997). Ocena oddziaływania na środowisko (OOŚ). Fachowa ekspertyza czy procedura $z$ udziałem społeczeństwa. Sytuacja w Polsce na tle tendencji światowych, Wrocław: BDE. ISBN 8390443872.

Kłobukowska, J. (2015). Partnerstwo publiczno-prywatne w finansowaniu infrastruktury sportowej $w$ Polsce. W: M. Tomanek, S. Raniszewski (red.), Problemy kultury fizycznej - aspekty ekonomiczne, prawne, pedagogiczne, Bydgoszcz: Akademia Sportu i Nauki, s. 70-78. ISBN 9788362750191.

Knowiton, E. (2016). Co zostaje $z$ ducha igrzysk olimpijskich? Obiekty sportowe kilkanaście lat później, Business Insider Polska, 10 sierpnia 2016, https://businessinsider.com.pl/sport/obiekty-olimpijskie-z-lat-1984-2004-zobacz-w-jakim-sastanie/qydklj9 [dostęp: 27.01.2019].

Krajewski, P. (2017). Prawo człowieka do środowiska jako potrzeba wielowymiarowych zależności i relacji człowieka z otoczeniem. W: E. Ura, B. Sitek, T. Graca (red.), Potrzeby jako wspótczesny determinant treści praw człowieka, Józefów: Wydawnictwo WSGE, s. 203-218. ISBN 9788362753864.

Pater, D. (2012). Współczesna myśl katolicka o wartości sportu $w$ życiu człowieka, Warszawskie Studia Teologiczne XXV/2, s. 213-220. ISSN 0209-3782.

Sitek, M. (2007). Polityka ochrony środowiska $w$ sektorze ustug turystycznych w świetle prawa Unii Europejskiej, Olsztyn: UWM. ISBN 9788372995117.

Słapek D. (2010). Sport i widowisko $w$ świecie antycznym: kompendium, Kraków - Warszawa: „Homini”. ISBN 9788361568605.

Štulajer, I. Štulajter, M. (2016). Significance of Sport in International Relations, „Journal of Modern Science" 2(29), s. 381-388. ISSN 1734-2031.

Szafrańska, E. Szafrański, J. (2014). Edukacja na rzecz bezpieczeństwa, „Journal of Modern Science" 2(21), s. 211-233. ISSN 1734-2031.

Winniczuk, L. (1983). Ludzie, zwyczaje i obyczaje starożytnej Grecji i Rzymu, Warszawa: PWN. ISBN 8301067357. 


\section{Dokumenty}

Ministerstwo Sportu i Turystyki, Ocena korzyści społecznych inwestycji w sport w odniesieniu do ponoszonych kosztów społecznych. Raport metodologiczny, lipiec 2016, s. 30-31.

Badanie specjalne Eurobarometru, Sport i aktywność fizyczna, październik 2009.

Program Rozwoju Sportu do roku 2020, file://Users/Bronek/Downloads/Program_Rozwoju_Sportu_do_roku_2020_-_wersja_z_dnia_6_lipca_2015.pdf [dostęp: 29.01.2019].

Ministerstwo Sportu i Turystyki, Obiekty lekkoatletyczne w Polsce. Inwentaryzacja bazy sportowej, Warszawa, maj 2017, https://www.msit.gov.pl/pl/infrastruktura/ opracowania/3719,Infrastruktura-sportowa.html [dostęp: 30.01.2019].

Ministerstwo Sportu i Turystyki, Sprawozdanie z realizacji przedsięwzięć EURO 2012 oraz z wykonanych działań dotyczacych realizacji przygotowań Polski do finałowego turnieju Mistrzostw Europy w Piłce Nożnej UEFA EURO 2012 (grudzień 2010 r. - czerwiec 2011 r.), Warszawa 2011, s. 287-288. 
